\section{Marleny Montilla'}

Hugo Soto"

Edgar Parra"II

Mariela Torres $^{\mathrm{IV}}$

Pilar Carrillo ${ }^{\mathrm{IV}}$

Ligia Lugo ${ }^{\mathrm{IV}}$

Johana Colorado"

Maria Teresa Arias"

Grupo de Parasitología. Instituto Nacional de Salud. Bogotá, DC, Colombia

"I Secretaria de Salud Departamental del Cesar. Valledupar, Cesar, Colombia

III Grupo de Patología. Instituto Nacional de Salud. Bogotá, DC, Colombia

iv Grupo de Entomología. Instituto Nacional de Salud. Bogotá, DC, Colombia

\section{Correspondence: \\ Mariela Torres \\ Laboratorio de Entomología \\ Instituto Nacional de Salud \\ Calle 26 51-20 Zona postal 6 \\ Cundinamarca \\ Apartados 80080 \\ 80334 Bogota, DC, Colômbia \\ E-mail:mtorres@ins.gov.co}

\section{Infestation by triatomine bugs in indigenous communities of Valledupar, Colombia}

\begin{abstract}
OBJECTIVE: To calculate triatomine infestation indices in indigenous communities in Colombia.
\end{abstract}

METHODS: A descriptive study was carried out in 19 communities in Valledupar Municipality, Cesar Department, Colombia. During June to December, 2007, triatromine bugs were collected from their resting places in households. Taxonomic identification was made according to the keys by Lent \& Wygodzinsky. An infection process in animal model and isozyme analysis of triatomine feces were performed.

RESULTS: Rhodnius prolixus showed a density index of $154.7 \%$, for Triatoma dimidiata was $102.45 \%$, T. maculata $109.25 \%$ and Panstrogylus geniculatus $0.3 \%$. The mean infestation index was $40.54 \%$, and mean Trypanosoma infection index was $9.4 \%$. Of five hemocultures positive for $T$. cruzi, three were enzimatically identified as T. cruzi group I. Biopsies revealed few pathologic characteristics of infective process with these strains isolated from domiciliary triatomine bugs.

CONCLUSIONS: The high triatomine infestation indices in households and the $T$. cruzi infection index are evidence of active transmission of Chagas disease. The situation merits a vector control program and serological survey of the population at risk. The genetic characterization of $T$. cruzi strains as group I agrees with other findings on strains in this region of Colombia.

DESCRIPTORS: Indigenous Population. Trypanosoma cruzi, isolation \& purification. Chagas Disease, prevention \& control. Triatominae, domiciliary infestation.

\section{INTRODUCTION}

Chagas disease is a problem for rural populations living in substandard housing and poor socioeconomic conditions. Residents of these regions were not reached by vector control programs since 2007 and have not received therapeutic treatment due to particular cultural conditions. ${ }^{24,23}$ At the end of the 1990s, the Program for Control of Trypanosoma cruzi Transmission and Child Cardiomyopathy in the main Endemic Areas of Colombia was initiated, including in Cesar and Guajira Departments. The goal was to determine priority indices for municipal attention. ${ }^{a}$ Nonetheless, indigenous communities of Valledupar municipality (Cesar) were not incorporated in the program.

\footnotetext{
angulo VM, Tarazona Z, Sandoval CM, Reyes A, Romero R. Programa Nacional de prevención y control de la infección por Trypanosoma cruzi, agente causal de la enfermedad de Chagas y cardiopatía infantil, en las principales áreas endémicas de Colombia. Departamentos de Cesar y Guajira. Nodo Nor-oriental CINTROP-UIS. Informe final. Diciembre 2000.
} 
The communities of Arhuacos, Wiwas and Koguis that have traditionally inhabited the northeastern slope of the Sierra Nevada of Saint Martha (SNSM) build their houses with local resources, such as wood and mud for walls, palm and straw for the roof and earth for the floor. These materials deteriorate with time and create abundant crevices conducive to development of $T$. cruzi triatomine vectors. Therefore, the house becomes the most important risk factor for transmission of Chagas disease. Although this region was not included in the national Chagas program, local investigations have described the epidemiologic situation of the indigenous communities, in Gogtsezhi and Kemacumumake ${ }^{18}$ with a report of $40 \%$ T. cruzi seroprevalence in 75 Amerindians, and Bunkwimake ${ }^{7}$ reports 19\% in 94 Amerindians. Both studies mentioned Rhodnius prolixus, Triatoma dimidiata, T. maculata and Panastrongylus geniculatus as triatomine species identified in houses.

Recently, cases of acute infections have been observed in residents of Seynimin, generating concern in the community over deaths that could eventually occur. Residents solicited medical care for patients and vector control measures from the authorities in health departments. This study sought to establish household entomological indices of communities in order to define the most suitable strategies for vector control and entomologic surveillance.

\section{METHODS}

The SNSM is located in the northeastern limits of Colombia, between 10 and 11 degrees north latitude and 72 and 74 degrees west longitude. It consists of a mountainous chain in pyramidal shape with a triangular base of $120 \mathrm{~km}$, extending from the Caribbean plain at sea level to $5,775 \mathrm{~m}$ of altitude at Bolívar and Colón peaks. The total land area of $21,158 \mathrm{~km}^{2}$ is divided by its slopes: the north slope, bordered by the plains of Guajira and the Caribbean Sea; the eastern slope delimited by the large alluvial plain of Magdalena river and the Ciénaga Grande de Santa Marta; the southwestern slope demarcated by the Racheria and Cesar rivers. It is has a special and unique geography in the world, with a high elevation, reaching a height of $5,700 \mathrm{~m}$ over a horizontal distance of $47 \mathrm{~km}$. It has all the thermal zones and six biomes of Colombia: humid forests with hot, temperate and cold thermal zones; and páramo, superpáramo and nival plain, engendering a wide diversity of floral and faunal species, with various endemic species. ${ }^{\mathrm{b}}$ The indigenous populations studied reside in the rural area of Valledupar municipality: Donachui, Isrwa, Piñamake, Sabana de Crespo, Seynimin, Tamacal, Timaca and Jugaka, of Arhuaca ethnicity; Arwamake, Auyamal, Cherua, Dungakare and Surimena, of Wiwa ethnicity; Avingue, Pueblo Hernández, Nakalindua, Sabanas de Higueron, Sarachui and San José de Marwamake of Kogui ethnicity.

Fieldwork was performed between June and December of 2007, in 19 localities of the three indigenous groups in Valledupar municipality. The indigenous personnel of the Entomology Laboratory of the Cesar Department Secretary performed systematic captures in the 19 communities, excluding houses whose occupants were not present at time of collection. There were also non-systematic capture of triatomines in some houses by residents. Specimens were given to personnel who transported them to the Entomology Laboratory in Valledupar.

A portion of the collected entomologic material was labeled, packed and sent to the Entomology Laboratory of the National Institute of Health (INS) for confirmation of taxonomic identification, using the key by Lent \& Wygodzinsky. ${ }^{15}$ To detect infection, the $T$. cruzi parasite was isolated by examining fresh triatomine feces, in a $0.85 \%$ sterile saline solution under a light microscope with $40 \mathrm{X}$ magnification. ${ }^{8}$

Inbred ICR mice were raised in the INS animal facility and used as a biologic model for the development and characterization of the $T$. cruzi infective process. A volume of $0.3 \mathrm{ml}$ of homogenized material obtained from each infected triatomine was inoculated in two mice by intraperitoneal injection. A total of 22 mice were exposed. Follow-up of the acute phase of parasitemia in mice was performed weekly for two months, by the crude drop method: a drop of blood, from the end of the tail, was examined under a light microscope with 40X magnification, analyzing 100 random fields to detect epimastigotes.

After two months, all blood was extracted (approximately $0.8 \mathrm{ml}$ ) by intracardial via and cultured under sterile conditions in Tobie media by triplicate. The cultures were maintained at $25^{\circ} \mathrm{C}$ for parasite development.

The eleven mice inoculated with homogenized trypomastigotes (T. cruzi) were sacrificed. Visceras (liver, heart, lower large intestine), brain, and skeletal muscle were extracted under sterile conditions in a laminar flow cabinet fixed in formaldehyde and processed in the Pathology Laboratory to be observed under a light microscope for analysis of histopathology. ${ }^{19}$

From the cultures in Tobie and LIT (liver infusion tryptose) media, three strains of $T$. cruzi were isolated and analyzed for isozymes by cellulose acetate electrophoresis, running five enzyme systems, $\mathrm{MDH}$, GPI, GDH, ME and IDH, according to the method by Godfrey \& Kilgour. ${ }^{11}$

\footnotetext{
b Instituto Geográfico Agustín Codazzi. Diccionario geográfico de Colombia. 3. ed. Bogotá: Horizonte Impresores; 1996. Tomo 4.
} 
The population of Seynimin was selected for the serological screening. During 2006 and 2007 respectively, 244 and 28 blood samples were collected on filter paper, from patients probably infected. This sample was sent to the Parasitology Laboratory of the INS for confirmation of $T$. cruzi antibodies by the indirect immunofluorescence (IF) method. ${ }^{3}$

A database was created in Excel ${ }^{\circledR}$ for information storage. Only entomologic indices are considered as risk factors associated with $T$. cruzi transmission. Factors associated with the house were not analyzed due to logistic difficulties in their sampling. Results are presented in percentages and indices.

\section{RESULTS}

The percentage of houses sampled in each community varied from $12 \%$ to $100 \%$. In total 1,431 houses were inspected: 394 of Kogui ethnicity, 179 of Wiwa ethnicity and 858 of Arhuaca ethnicity; of the total, 438 were infected by triatomines (43.7\%). The triatomine species identified by the Entomology Laboratory were $R$. prolixus, T. dimidiata, T. maculata, and $P$. geniculatus. The entomological indices for the different populations are presented in Table 1, which shows $R$. prolixus as the predominant species with a density index of $154.7 \%$, followed by $T$. maculata with $109.25 \%$ and $T$. dimidiata with $102.45 \%$. Infestation by $P$. geniculatus was very low, and its density index was $0.3 \%$. In the 19 localities inspected, the average triatomine infestation index was $40.5 \%$, with a colonization index of $32.0 \%$. The $T$. cruzi infection index in the sample sent to INS was $9.4 \%$.

It was not possible to observe development of any parasitemia in the blood of mice inoculated with the infectious homogenized trypomastigotes. The mice behaved and appeared healthy while infected. Nonetheless, cultures inoculated with intracardial blood from five mice developed parasite epimastigotes: two mice infected with homogenized material of $R$. prolixus, from Sarachui (Kogui ethnicity); one mouse infected with homogenized material of R.prolixus from Isrwa (Arhuaca ethnicity); and two mice infected with homogenized material of T. maculata, from Sabanda de Crespo and Isrwa (Arhuaca ethnicity).

Of the five blood cultures that presented $T$. cruzi epimastigotes, three were classified by isoenzymes as $T$. cruzi group I, belonging to $R$. prolixus and T. maculata collected in homes of people in Isrwa and Sabana de Crespo (Arhuaca ethnicity).

Biopsies of mice inoculated with infectious homogenized $T$. cruzi trypomastigotes were analyzed by light microscope. All strains had similar histopathological behavior (Table 2). Four mice presented myositis and myocarditis, characteristic of the infective process.
Among the 11 inoculated mice, only two presented intracellular T. cruzi amastigotes, from feces of $R$. prolixus collected in Sarachui locality (Kogui ethnicity); nonetheless, no mice presented a significant lesion in histopathological analysis.

In samples analyzed by IF from the population of Seynimin, positivity levels of $0.8 \%(2 / 244)$ and $28 \%$ $(8 / 28)$ were obtained for 2006 and 2007 , respectively.

\section{DISCUSSION}

The entomological indices for infestations (average 40.5\%) and colonization (average 32.0\%) demonstrate that infestation by triatomines is a widespread and important problem in 16 of the 19 indigenous locations inspected in Valledupar municipality. Although an evaluation of housing conditions was not performed, an association can be established between the perishable materials used for construction and the proximity to the ecosystems as factors that allow the development of dense triatomine populations. Recently, other high risk factors for triatomine infestation have been considered, such as the number of inhabitants per household in communities, storage density of household objects and the presence of barns and domestic animals, ${ }^{5}$ but these were not evaluated in this study. In examining the association between housing, triatomine infestation and the transmission of T. cruzi, it is necessary to consider the cultural and religious meanings that the house has for indigenous communities of the SNSM. When designing an intervention and vector control program, any modification in type of construction material should be discussed with the community.

The triatomine species identified in this study are the same registered by other municipalities in Cesar. ${ }^{\text {a }}$ The process for dispersion of $R$. prolixus, T. maculata, $T$. dimidiata and $P$. geniculatus probably has not faced barriers of biogeography and/or the type of culture among indigenous communities in the region. ${ }^{17,18} R$. prolixus was found in greatest density, followed by $T$. maculata and $T$. dimidiata. The two later species had a significant and important dispersion, considering the large proportion of houses inspected.

Parasitological diagnosis reveals a high number of triatomines infected by $T$. cruzi (infection index of 9.4\%), especially $R$. prolixius and T. maculata. These findings confirm that the risk for Chagas disease is high, although a fraction of the total sample of triatomines was analyzed. In Seynimin community, the percentage of Chagas disease in children, corresponds to a point estimate for the indigenous population of SNSM, although children close the parasite transmission cycle and communities emphasize that Chagas disease begins at an early age in the Amerindians of these communities 


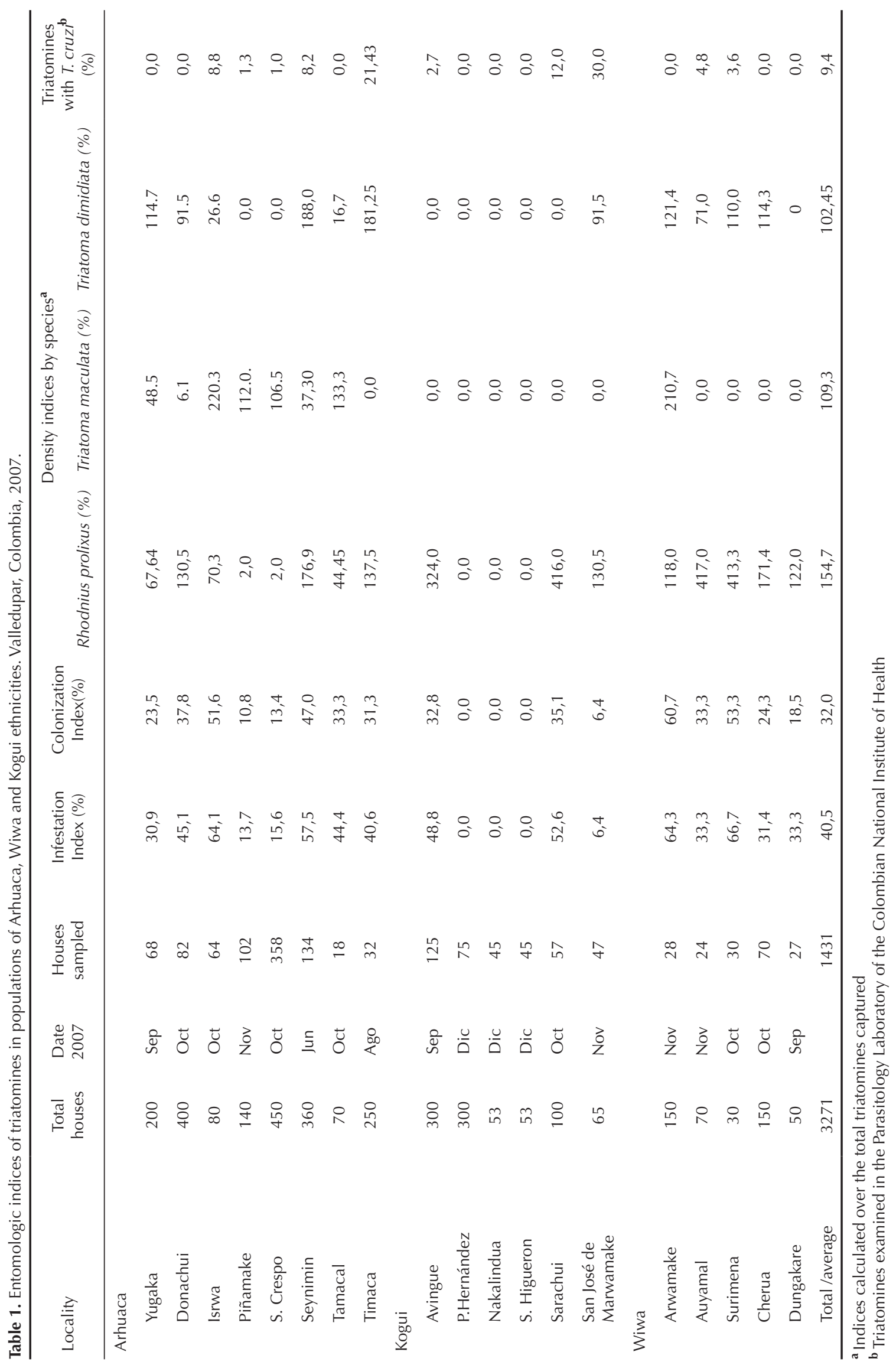




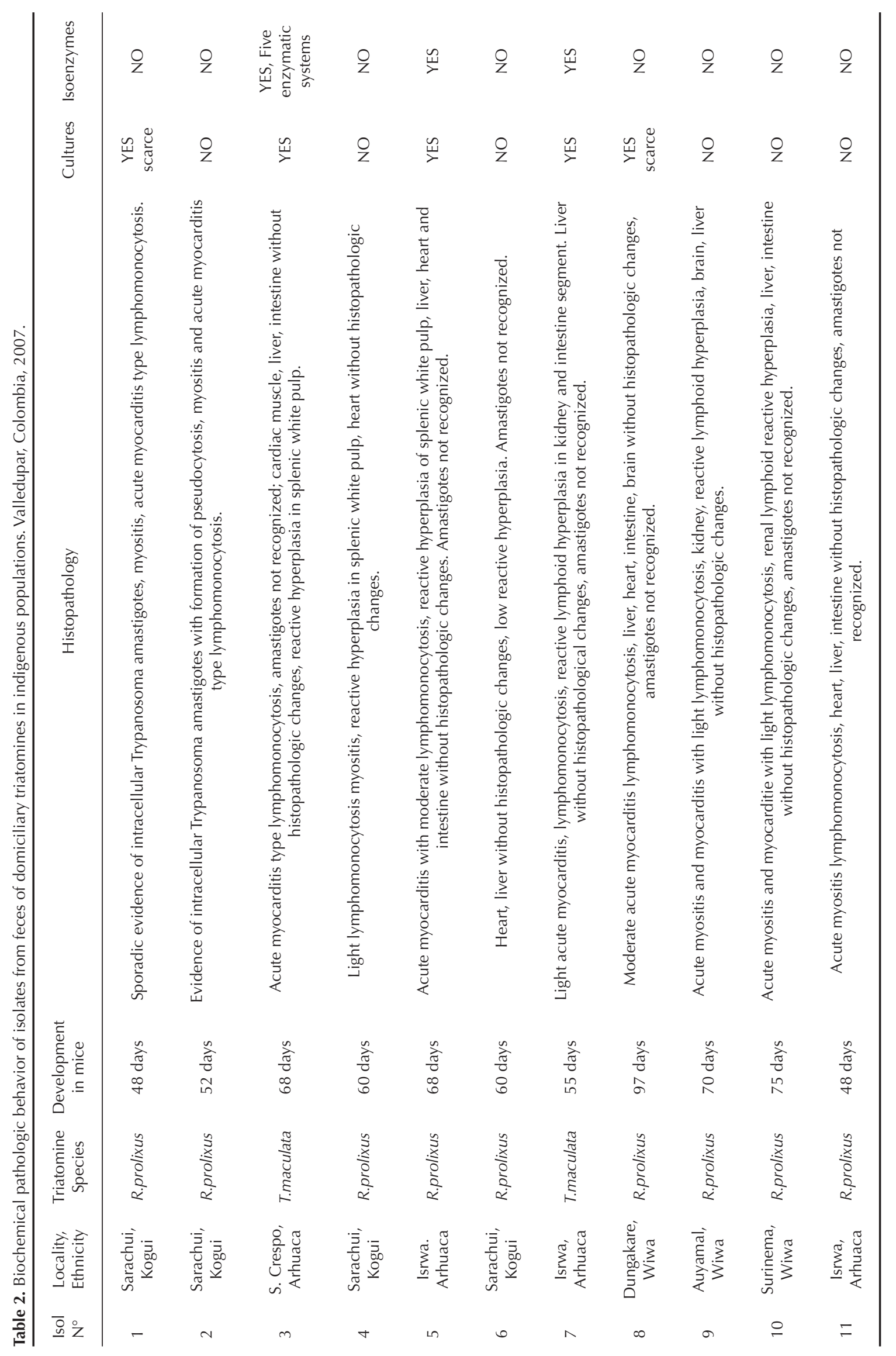


The parasitological test of feces and the histopathological characterization of biopsies from infected inbred ICR mice, together with the isoenzymatic analysis of blood cultures for parasites, produced similar results as obtained in experimental conditions of strains from a distinct origin. ${ }^{20}$ The results allow for identification of the group and some characteristics of histopathological behavior of $T$. cruzi from the triatomines collected in these indigenous communities.

In regards to the distribution of $T$. cruzi strains, molecular characterization studies performed in Latin American countries have recognizes two well differentiated lineages. T. cruzi II is located in the south of the continent (Paraguay, Chile, Argentina and part of Brazil), with human isolates, ${ }^{10,14,22}$ and Triatoma infestans as the main domiciliary vector. ${ }^{22}$ In Central American countries and northern South America, the main vectors are $R$. prolixus and $T$. dimidiata, ${ }^{22}$ and most isolates come from humans, corresponding to T. cruzi group I. ${ }^{1,6,14}$ Considering this distribution, the three strains of $T$. cruzi from triatomines in Cesar Department coincide with group I T. cruzi, circulating in humans. These results agree with recent findings for strains isolated from diverse hosts in different regions of Colombia, indicating that this group of $T$. cruzi predominates in Colombia., ${ }^{9,12,13,16,21}$

The biological and parasitological behavior described in the post-inoculation phase, without apparent parasitemia in mouse periphery blood could be defined as another characteristic specific to strains belonging to T. cruzi I and confirm the findings of a previous study. ${ }^{2}$

On the other hand, histopathological results show myositis as a common lesion in mice inoculated with infectious homogenized T. cruzi and support the pathological behavior previously identified, ${ }^{2,4,23}$ using mice as an animal model for Chagas disease.
Although these strains of $T$. cruzi group I do not produce parasitemia visible in peripheral blood, they do present a positive tropism in cardiac tissue of mice and produce light lesions in this organ that do not lead to host death. Therefore, they are classified as strains poorly adapted to the host, a situation previously observed by other investigators in Colombia. ${ }^{c}$

In considering the careful follow-up of parasite cultures, the T. cruzi clones that produced the histopathological traits are the same that grew in the culture media. Nonetheless, there is a possibility that post-inoculation clonal selection of $T$. cruzi may have occurred, a process described by Botero et $\mathrm{al}^{4}$ as the result of the host immune system, in this case ICR mice.

In conclusion, infestation by triatomines infected with T. cruzi is a serious problem in the houses studied, impacting on transmission of Chagas disease as verified by some human cases. There is an urgent need for appropriate and concerted vector control strategies in these communities. Entomologic surveillance and serologic screening should be expanded to all 104 indigenous communities in SNSM in order to reach environmental and epidemiological coverage of the entire transmission foci.

T. cruzi group I, a parasite that infects triatomines in the houses of these Amerindians, coincides with the predominant group in Central America and northern South America, commensurate to the vector dispersion. This finding is striking considering the relative cultural and bio-ecological isolation of indigenous communities in SNSM.

Lastly, when selecting techniques for detection, multiplication and classification of parasites from vectors, it is reasonable to consider that some T. cruzi strains found in triatomine feces may not infect vertebrate hosts since the immunologic system exerts a selective action against certain lines.

\footnotetext{
' Vallejo G, Laboratory of Tropical Parasitology Investigations, University of Tolima, Colombia, personal communication.
} 


\section{REFERENCES}

1. Añez N, Crisante G, da Silva FM, Rojas A, Carrasco H, Umezawa ES, et al. Predominance of lineage I among Trypanosoma cruzi isolates from Venezuelan patients with different clinical profiles of acute Chagas' disease. Trop Med Int Health. 9(12):1319-26. DOl:10.1111/ j.1365-3156.2004.01333.x

2. Barrera YK, Guevara JM, Pavía PX, Montilla M, Nicholls RS, Parra E, et al. Evaluación de las pruebas de PCR TcH2AF-R y S35-S36 para la detección de Trypanosoma cruzi en tejido cardiaco de ratón. Biomédica. 2008;28(4):616-26.

3. Botero D, Restrepo M. Parasitosis humanas. CIB. 3. ed Medellín: CIB; 1998.

4. Botero LA, Mejia AM, Triana O. Caracterización biológica y genética de dos clones pertenecientes a los grupos I y II de Trypanosoma cruzi de Colombia. Biomédica. 2007;27 Supl 1:64-74.

5. Campbell-Lendrum DH, Angulo VM, Esteban L, Tarazona Z, Parra GJ, Restrepo M, et al. House-level risk factors for triatomine infestation in Colombia. Int J Epidemiol. 2007;36(4)866-72. DOI:10.1093/ije/ dym065

6. Cuervo P, Cupolillo E, Segura I, Saravia N, Fernandes O. Genetic diversity of Colombian sylvatic Trypanosoma cruzi isolates revealed by the ribosomal DNA. Mem Inst Oswaldo Cruz. 2002;97(6):877-80. DOI:10.1590/S0074-02762002000600023

7. Dib JC, Agudelo LA, Vélez ID. Prevalencia de patologías tropicales y factores de riesgo en la comunidad indígena Bunkwimake, Sierra Nevada de Santa Marta. Duazary. 2006;3(1):38-44.

8. Duque S, Peláez D, Gualdrón LE, Villarreal E, Corredor-Arjona A. Aislamiento de tripanosomas a partir de materia fecal de Rhodnius prolixus. Biomédica. 1988;8:37-9.

9. Falla A, Herrera C, Fajardo A, Montilla M, Vallejo GA, Guhl F. Haplotype identification within Trypanosoma cruzi I in Colombian isolates from several reservoirs, vectors and humans. Acta Tropica. 2009;110(1):26-34. DOI:10.1016/j.actatropica.2008.12.003

10. Fernandes O, Souto RP, Castro JA, Pereira JB, Fernandes NC, Junqueira ACV, et al. Brazilian isolates of Trypanosoma cruzi from human and triatomines classified into two lineages using mini-exon and ribosomal RNA sequences. Am J Trop Med Hyg. 1998;58(6):807-11.

11. Godfrey DG, Kilgour A. Enzyme electrophoresis in characterizing the causative organism of Gambian trypanosomiasis. Trans Roy Soc Trop Med Hyg. 1976;70(3):219-24

12. Herrera C, Bargues MD, Fajardo A, Montilla M, Triana O, Vallejo GA, et al. Identifying four Trypanosoma cruzi I isolated haplotypes from different geographic regions in Colombia. Infect Genet Evol. 2007;7(4):5359. DOI:10.1016/j.meegid.2006.12.003
13. Herrera C, Guhl F, Falla A, Fajardo A, Montilla M, Vallejo GA, Bargues MD. Genetic variability and phylogenetic relationships within Trypanosoma cruzi I isolated in Colombia based on miniexon gene sequences. J Parasitol Res. 2009;2009:897364. DOI; $10.1155 / 2009 / 897364$

14. Higo, H, Miura S, Horio M, Mimori T, Hamano S, Agatsuma T, et al. Genotypic variation among lineages of Trypanosoma cruzi and its geographic aspects. Parasitol Int. 2004; 53(4):337-44. DOI:10.1016/j. parint.2004.06.001

15. Lent H, Wygodzinsky P. Revision of the Triatominae (Hemiptera: Reduviidae) and their significance as vectors of Chagas disease. Bull Am Mus Nat Hist. 1979;163:127-520.

16. Montilla M, Guhl F, Jaramillo C, Nicholls S, Barnabe C, Bosseno F, et al. Isoenzyme clustering of Trypanosomatidae Colombian populations. Am J Trop Med Hyg. 2002;66(4):394-400.

17. Parra-Henao G, Angulo V, Jaramillo N, Restrepo M. Triatominos (Hemiptera: Reduviidae) de la Sierra Nevada de Santa Marta, Colombia: aspectos epidemiológicos, entomológicos y de distribución. CES Med, 2009;23(1):17-26.

18. Parra-Henao GJ, Restrepo Isaza M, Restrepo BN, Domínguez JD. Estudio de tripanosomiasis americana en dos poblados indígenas de la Sierra Nevada de Santa Marta, Colombia. CES Med. 2004;18(1):43-50.

19. Prophet EB, Mills B, Arrington BA, Sobin MD. Laboratory methods in histotechnology. Washington, DC: Armed Forces Institute of Pathology; 1992.

20. Rodríguez P, Montilla M, Nicholls S, Zarante I, Puerta C. Isoenzymatic characterization of Colombian strains of Trypanosoma cruzi. Mem Inst Oswaldo Cruz. 1998;93(6):739-40. DOI:10.1590/S007402761998000600008

21. Rodríguez IB, Botero A, Mejía-Jaramillo AM, Marquez EJ, Ortiz S, Solari A, et al. Transmission dynamics of Trypanosoma cruzi determined by low-stringency single primer polymerase chain reaction and Southern Blot analyses in four Indigenous communities of the Sierra Nevada de Santa Marta, Colombia. Am J Trop Med Hyg. 2009;81(3):396-403.

22. Souto R, Fernandes O, Macedo AM, Campbell DA, Zingales B. DNA markers define two major phylogenetic lineages of Trypanosoma cruzi. Mol Biochem Parasitol. 1996;83(2)141-52. DOI:10.1016/ S0166-6851(96)02755-7

23. Téllez-Meneses J, Mejía-Jaramillo AM, Triana-Chávez O. Biological characterization of Trypanosoma cruzi stocks from domestic and sylvatic vectors in Sierra Nevada of Santa Marta, Colombia. Acta Tropica. 2008;108(1):2634. DOI:10.1016/j.actatropica.2008.08.006

24. World Health Organization. Control of Chagas disease: 2nd report of the WHO Expert Committee. Geneva; 2002. (WHO Technical Report Series, 905). 